Volume 3 Issue 1 (2019) Pages 82 - 90

Jurnal Obsesi : Jurnal Pendidikan Anak Usia Dini

DOI: $10.31004 /$ obsesi.v3i1.111

\title{
Pendekatan Kontekstual dalam Meningkatkan Hasil Belajar Sains pada Anak Usia Dini
}

\author{
Sri Watini ${ }^{1 凶}$ \\ Dosen PG-AUD STKIP Panca Sakti Bekasi
}

\begin{abstract}
The purpose of this study is to improve learning outcomes using a contextual approach. By using a contextual approach it is expected that the results of learning sciences in early childhood will increase and be more meaningful. The population in this study were children aged 5-6 years in PAUD Cempaka Pekayon with a total of 18 children. The study was conducted in October-December 2015. The research method used is Classroom Action Research. This method has four stages. 1) planning stage, 2). implementation stage, 3). observation stage and 4) reflection stage. The implementation of this activity was carried out in three cycles. The results of the study are indicated by an increase in science learning outcomes. Percentage of cognitif cycle I of $58.5 \%$, affective domain $47.1 \%$, psychomotor domain $56.1 \%$. Percentage of cognitive cycle II cycle $66.7 \%$, affective domain $59 \%$, psychomotor domain $65.7 \%$. Percentage in the third cycle of cognitive domain $78.9 \%$, affective domain $84.1 \%$, psychomotor domain $84.3 \%$.
\end{abstract}

Keywords: contextual approach, sains competence, early childhood education

\begin{abstract}
Abstrak
Penelitian ini memiliki tujuan untuk meningkatkan hasil belajar sains dengan menggunakan pendekatan kontekstual. Dengan menerapkan pendekatan ini diharapkan hasil belajar sains pada anak akan meningkat dan lebih bermakna. Subjek penelitian ini adalah anak usia 5-6 tahun di PAUD Cempaka Pekayon dengan jumlah 18 anak. Penelitian dilaksanakan pada Bulan Oktober- Desember 201. Metode penelitian adalah PTK (Penelitian Tindakan Kelas). Adapun dalam metode ini terdiri dari empat tahapan yaitu 1) tahap perencanaan, 2). tahap pelaksanaan, 3). tahap pengamatan dan 4) tahap refleksi. Pelaksanaan dalam kegiatan ini dilakukan dalam tiga siklus. Hasil penelitian ditunjukkan dengan adanya peningkatan hasil belajar sains dengan prosentase perolehan pada siklus I ranah kognitif 58,5\%, ranah afektif $47,1 \%$, ranah psikomotorik $56,1 \%$, siklus II ranah kognitif $66,7 \%$, ranah afektif $59 \%$, ranah psikomotorik $65,7 \%$ dan pada siklus III ranah kognitif $78,9 \%$, ranah afektif $84,1 \%$, ranah psikomotorik $84,3 \%$.
\end{abstract}

Kata Kunci : Pendekatan Kontekstual, Hasil Belajar Sains, Anak Usia Dini 5-6 Tahun

@ Jurnal Obsesi Prodi PG-PAUD FIP UPTT 2019

$\triangle$ Corresponding author:

Address : Jalan Patuha Utara Kayuringinjaya Bekasi

ISSN 2356-1327 (Media Cetak)

Email:s srie.watini@gmail.com

ISSN 2549-8959 (Media Online) 


\section{PENDAHULUAN}

Hakikat pendidikan merupakan upaya mengembangkan potensi anak agar dapat berkembang secara optimal. Hakikat Pendidikan Anak Usia Dini adalah suatu proses pemberian rangsangan agar potensi yang ada pada anak dapat berkembang secara optimal. Pada saat inilah anak sedang mengalami masa golden ages atau masa ke emasan di mana sel syaraf otak sedang mengalami perkembangan yang sangat pesat. Hal inilah yang akan mempengaruhi seluruh aspek perkembangan anak. Pentingnya menciptakan proses pembelajaran yang baik wajib dilakukan oleh pendidik agar hasil belajar anak menjadi bermakna (meaningfull) sehingga hasil belajar dapat difungsikan dalam kehidupan anak seharihari secara nyata. Perkembangan sains dan teknologi yang sangat pesat saat ini memiliki efek yang sangat luar biasa bagi kehidupan anak, untuk itulah maka guru harus benar-benar menfasilitasi anak dalam proses pendidikannya sehingga setelahnya anak memiliki beradaptasi dengan baik dengan segala perubahan yang ada serta mampu mengambil sikap kreatif dan inovatif dalam langkah tindakannya. Guru dituntut harus mampu menciptakan situasi dan kondisi pembelajaran di mana anak akan dapat mengkonstruksi pengetahuan, keterampilan, sikap dan nilai serta dapat merefleksikan dalam berpikir dan tindakan. Oleh sebab itulah maka guru harus memilih dan menetapkan strategi pembelajaran yang tepat baik dalam pemilihan model, metode, pendekatan, teknik dan taktik yang tepat. Dengan strategi yang tepat inilah maka proses pembelajaran akan berjalan secara efektif, efesien dan relevan. Relevan di sini baik dalam sisi kebutuhan belajar anak, perkembangan zaman serta sesuai dengan berbagai unsur-unsur penting lainnya. Oleh sebab itu pembelajaran anak terhadap ilmu sains atau lingkugan alam adalah pilihan tepat dalam mengenalkan anak tentang kebermaknaan lingkungan sebagai inspirasi dalam kehidupan. Pendekatan kontekstual (Contextual learning Approach) dalam pembelajaran sains dalam penelitian ini sebagai suatu pilihan penelitian dalam action guru melakukan perbaikan pendidikan khususnya dalam perbaikan hasil belajar. Pengenalan alam sekitar merupakan salah satu aspek pengembangan potensi anak dalam mengenal sains permulaan. Melalui pengenalan sains permulaan anak dapat mulai mengenal konsep-konsep sains secara sederhana. Dalam pembelajaran ini anak akan membangun pengetahuan, keterampilan, sikap dan pengalaman melalui pola pikir ilmiah, sistematis dan obyektif melalui keterampilan proses sains sederhana. Namun dalam kenyataannya selama ini dalam pembelajaran sains permulaan belum optimal. Pembelajaran sains masih dilakukan di dalam kelas, monoton dan bersifat verbalistik atau hafalan. Ditambah dengan keadaan ruang-ruang kelas yang sempit serta minmnya penguasaan guru terhadap sains. Media konkrit yang ada di alam sekitarpun belum dijadikan sebagai media efektif dalam pembelajaran.

Berdasarkan latar belakang inilah maka peneliti tertarik untuk melakukan penelitian tentang bagaimana pembelajaran sains permulaaan pada anak usia dini khususnya kelompk B usia 5-6 tahun dengan menerapkan pendekatan kontekstual. Melalui Penelitian Tindakan Kelas (Action Reseacrt) diharapkan akan meningkatkan hasil belajar sains secara optimal.

Belajar merupakan keharusan bagi manusia yang hidup di dunia. Hal ini bertujuan agar manusia mampu menghadapi kehidupannya. Dalam proses belajar tidak ada batasan usia. Dari manusia itu lahir 
sampai akhir hayatnya harus tetap terus belajar dalam rangka untuk memperoleh ilmu yang bermanfaat. Dalam kesepakatan UNESCO belajar adalah sepanjang hayat atau "life long education" Menurut (Slameto 2003, 2) "Belajar merupakan suatu proses untuk memperoleh suatu perubahan tingkah laku yang baru secara keseluruhan, sebagai hasil dari pengalaman sendiri dalam berinteraksi dengan lingkungannya." Peaget dalam (Dimyati and Mudjiono 2006, 13) berpendapat bahwa pengetahuan dibentuk oleh individu dengan cara melakukan interaksi secara terus menerus dengan lingkungannya di mana lingkungan tersebut selalu mengalami perubahan. Melalui interaksi itulah maka fungsi intelek semakin berkembang. Menurut Peaget dalam (Sujiono 2006, 3435) "Proses belajar disesuaikan dengan tahapan berpikir atau tahapan perkembangan intelektual yang dimiliki oleh seseorang. Adapun tahapan berpikir tersebut adalah: 1) Tahap sensorimotorik (usia 0-2 tahun), 2) Tahap Praoperasional (usia 2-7) tahun), 3) Tahap Operasional Konkrit (7-11 tahun), 4), Tahap Operasional Formal (11 tahun sampai dewasa). Dari penjelasan tersebut berarti anak usia taman kanak-kanak adalah dalam tahap praoperasional dalam hal ini berkisar 5-6 tahun. Untuk itu maka diharapkan dalam proses pembelajaran harus sesuai dengan tahapan perkembangan anak.

Hasil belajar merupakan sebuah umpan balik setelah seseorang melakukan proses belajar. Oleh sebab itu dengan belajar sungguh-sungguh maka akan memperoleh hasil belajar yang optimal. Hal ini didukung oleh kajian teori yang dinyatakan oleh (Sujana 2005) bahwa hasil belajar adalah kemampuan-kemampuan yang dimiliki oleh siswa setelah ia menerima pengalaman belajarnya. Sedangkan menurut (Usman 1989, 29) bahwa tujuan hasil belajar memiliki tiga ranah yaitu ranah kognitif, afektif dan psikomotorik. Hasil dari kategori tersebut dapat diukur baik sendiri-sendiri maupun secara bersamaan. Sementara (Hapidin and Gunarti 1997, 68) mengklasifikasikan tiga ranah atau tiga domain hasil belajar tersebut antara lain: 1) Ranah Kognitif berkaitan dengan perhatian pengembangan kapabilitas dan keterampilan intelektual, 2) Ranah Afektif berkaitan dengan pengembangan perasaan, sikap, nilai dan emosi dan 3) Ranah Psikomotorik berkaitan dengan kegiatan-kegiatan atau keterampilan-keterampilan motorik atau gerakan.

Nash dalam (Darmojo and Kaligis 1991, 3) mengatakan bahwa "Sciences is a way of looking at the word." Sains disini merupakan suatu cara atau metode untuk memperoleh berbagai ragam pengetahuan alam melalui aktivitas yang analitis, lengkap dan sistematis serta obyektif sehingga dapat menghubungkan antara fenomena alam yang satu dengan fenomena alam yang lainnya pada akhirnya akan memperoleh atau membentuk perspektif baru yang lebih komplek tentang obyek yang diamati. Adapun menurut Webster's “ New Lollegiete Dictionary dalam (Iskandar and Hidayat 1997, 2) menyatakan "Natural Sains knowledge concerned with the physical word and its's phenomena" yang artinya bahwa sains merupakan pengetahuan tentang alam dan gejalagejalanya. Menurut Einstain dalam (Darmojo and Kaligis 1999, 5-13), "Sains merupakan suatu bentuk upaya yang membuat berbagai pengalaman menjadi sistem pola pikir yang logis yaitu dengan metode ilmiah. Artinya bahwa sains merupakan pengetahuan tentang alam dan gejala-gejalanya. Sedangkan menurut dalam (Darmojo and Kaligis 1991, 3) menyatakan bahwa "Sains merupakan suatu sistem 
untuk mengetahui alam sekitar dan sains juga merupakan suatu sekumpulan pengetahuan yang berfungsi untuk menjelaskan apa yang telah diperoleh. Sains merupakan ilmu yang mempelajarai tentang suatu fenomena yang spesifik serta sains adalah suatu proses kegiatan atau tindakan dalam rangka memecahkan masalah.

Sains permulaan untuk anak usia dini khususnya anak usia kelompok B (5-6 tahun) disajikan melalui kegiatan bermain yang menyenangkan, bermanfaat serta terarah dalam rangka mereka memahami dunia sekitarnya. Sains pada anak usia ini harus melibatkan anak secara aktif sesuai dengan kajian teori belajar dan tahapan perkembangannya sehingga hasil belajar yang diperoleh menjadi lebih bermakna dalam kehidupannya. (Rogers and Sawyers 1995, 3) "Melalui kegiatan bermain yang menyenangkan anak dapat belajar tentang sebab akibat atau perubahan. Dari pernyataan ini terkandung makna bahwa dengan melalui kegiatan bermain sesungguhnya anak melakukan proses belajar dalam rangka untuk memperoleh berbagai informasi ilmu pengetahuan dengan cara yang menyenangkan, menikmati sukarela tanpa adanya unsure keterpaksaan. Pada hakikatnya tujuan hasil belajar sains permulaan dalam rangka mengembangkan sikap positif anak terhadap alam semesta. Menurut Wynne Harlen dalam (Darmojo and Kaligis 1999, 5-13) bahwa tujuan hasil belajar sains permulaan memiliki sembilan aspek sikap ilmiah yang terdiri dari , a) Sikap ingin tahu (curiosity), b) Sikap ingin mendapatkan sesuatu yang baru (originality), c) Kerjasama (co operation), d) Sikap tidak putus asa (perseverance), e) Sikap tidak berprasangka, f) Sikap mawas diri (self critism), g) Sikap bertanggung jawab (responsibility), h) Sikap berpikir bebas (independence in thinking) dan i) Sikap Kedisiplinan diri( Self discipline.

Kemampuan kognitif anak usia 5-6 tahun (Anak kelompok B) berada dalam tahapan praoperasional konkrit (Suyanto 2005, 53-56). Tahapan praoperasional konkrit ini memiliki beberapa karakteristik dalam kemampuan kognitif hubungannya dengan kemampuan berpikir atau bernalar yang bisa diidentifikasi. Karakteristik dalam dilihat dari keingintahuan yang tinggi, egosentris, berpikir statis, pikiran dan perbuatannya dipengaruhi dari luar, berpikir selalu kedepan, dan mulai dapat mengenal penambahan, pengurangan, dan klasifikasi atas dasar bentuk lainnya.

Early Chilhood Education Preschool Through Primary Grades, University of Maddachusett Lowell: Pearson (Brewer 2007, 386), "Dalam proses pembelajaran sains pada anak usia dini terdapat beberapa kriteria yang sesuai bagaimana anak-anak usia dini dalam belajar sains antara lain : a) Anak berpartisipasi secara aktif, b) Memberikan kesempatan pada anak untuk melakukan berbagai tindakan sesuai dengan keinginannya dan bertanggunjawab. c) Bercermin dari pertanyaan guru serta berbagai fokus permasalahan sehingga anak melakukan berbagai aktifitas kegiatan , mengamati, mencari tahu tentang suatu fenomena, d) Melakukan kegiatan penyelidikan mengenai berbagai konsep dasar sains, d) Memberikan berbagai variasi pengalaman dan kesempatan secara spontan pada anak yang direncanakan, e) Mengeksplorasi berbagai materi pengetahuan tentang sains seperti mahkluk hidup dan bumi, f) Pengetahuan dan Keterampilan anak dinilai dengan berbagai cara.

Dalam setiap kegiatan proses pembelajaran tentulah menggunakan berbagai media dan sumber belajar dalam rangka mendukung tercapainya tujuan 
pendidikan yang sudah ditentukan. Begitu pula dalam pembelajaran sains juga tidak terlepas dari media dan sumber belajar yang akan digunakan sesuai dengan tujuan (Arsyad 1997, 20). Dalam pembelajaran sains ini media yang digunakan untuk sarana belajar para siswa dapat menggunakan bahan-bahan yang tersedia di dunia nyata dalam kehidupan sehari-hari di dekatnya. Menurut uraian di atas maka dapat dijelaskan bahwa apa saja yang ada di lingkungan kehidupan anak dapat dijadikan sebagai media pembelajaran.

Pendekatan belajar kontekstual adalah konsep belajar yang mendorong guru untuk untuk memberikan materi yang diajarkan sesuai dengan situasi dunia nyata (Mulyadi 2007, 133). Dengan menerapkan pendekatan ini diharapkan anak akan lebih mudah dalam belajar. Menurut (Departemen Pendidikan Nasional 2003, 3) Pendekatan belajar kontekstual adalah suatu proses pendekatan pembelajaran yang meliputi relating, experiencing, appliying, cooperating dan transfering. Menurut (Nurhadi 2004, 107) adapun ciri-ciri dari pendekatan belajar kontekstual ini adalah sebagai berikut: 1) Memberikan pengalaman nyata bagi anak, 2) Kerjasama, 3) Saling menunjang, 4) Fun dan Enjoy dalam belajar, 5) Belajar dengan bergairah, 6 ) Sharing dengan sesama, 7) Guru harus kreatif.

Pada proses pembelajaran sains permulaan dengan pendekatan belajar kontekstual adalah dengan cara anak membagun pengetahuan melalui berbagai kegiatan yang mengaktifkan anak mulai dari pengamatan atau observasi, membuat dugaan sementara atau hipotesis sederhana, mengkomunikasikan sampai pada membuat kesimpulan dan laporan sederhana. Dalam proses pembelajarannya guru hanya sebagai pengarah dan pembimbing kegiatan, baik sebagai fasilitator maupun mediator. Dalam rangka mengaktifkan anak agar lebih optimal dalam proses kegiatan belajar maka kegiatannya tidak harus ada dalam ruang kelas akan tetapi bisa dilakukan diluar kelas.

Dalam prosesnya guru hendaklah meminimalisir kegiatan ceramah. Di sini guru harus banyak memmberikan peluang atau kesempatan agar anak beraktivitas. Menurut (Mulyasa 2003, 186) Guru yang berhasil dalam membelajarkan siswa adalah : 1) Guru yang selalu melakukan observasi terhadap semua kegiatan dalam situasi dan kondisi apapun, 2) Selalu menyediakan dan meluangkan waktu untuk berdiskusi dengan anak-anak , 3) Selalu memberikan evaluasi yang konstruktif, 4 ) Mencatat semua aspek perkembangan yang ada pada anak selama proses pembelajaran berlangsung 6). Membuat latihan-latihan,

Evaluasi atau penilaian dalam belajar sains merupakan kemajuan atau peningkatan anak dalam memperoleh prestasi hasil belajar. Menurut Menherns dan Lehman (Nasution 1996, 7) menyatakan bahwa evaluasi atau penilaian merupakan suatu pertimbangan yang profesional atau suatu proses yanng memungkinkan seseorang membuat suatu pertimbangan mengenai nilai sesuatu. Pengambilan keputusan berdasarkan pada kenyataan yang sesungguhnya atau obyektif

\section{METODOLOGI}

Metode yang digunakan dalam penelitian ini adalah Metode Penelitian Tindakan Kelas (Classroom Action Reseacrh). Hal ini berdasrkan pada latar belakang dan tujuan penelitian. Menurut Hopkins dalam (Widiaatmadja 2008, 11), "Metode Penelitian Tindakan Kelas adalah Penelitian yang mengkombinasikan prosedur peneltian dengan tindakan subtantif yaitu suatu tindakan yang dilakukan dalam disiplin inkuiri atau suatu 
usaha seseorang untuk memahami perbaikan dan perubahan".

Penelitian tindakan kelas merupakan sebuah penelitian tindakan dalam bentuk inkuiri reflektif yang dilakukan secara kemitraan mengenai situasi sosial tertentu termasuk dalam dunia pendidikan untuk meningkatkan rasionalitas dan keadilan dari a) kegiatan praktek social atau pendidikan, b) pemahaman mereka mengenai kegiatankegiatan praktek pendidikan dan c) situasi yang memungkinkan terlaksananya kegiatan praktek. Penelitian Tindakan Kelas ini bertujuan dalam rangka untuk meningkatkan profesioalitas guru dalam meningkatkan hasil belajar atau prestasi peserta didik dengan melalui kegiatan refleksi diri dari masing-masing guru atau pendidik yang bersangkutan. Melalui refleksi diri ini diharapkan guru atau pendidik mampu merenungkan serta merencanakan berbagai tindakan-tindakan lanjutan guna meningkatkan dan memperoleh hasil belajar atau prestasi anak agar lebih maksimal.

Desain Intervensi Tindakan dalam penleitian ini menggunakan Model Kemmis dan Mc.Taggart. Ada tiga tahapan dalam Model Kemmis dan Mc. Taggart dalam (Suharsimi 2006, 97) antara lain: a).Tahap Perencanaan (Planning), b).Tahap Pelaksanaan Tindakan (Action), dan. Pengamatan (Observing), c).Tahap Refleksi (Reflection) dan seterusnya sampai terselesaikannya refleksi dan tindakan selanjutnya". Pada tahap awal yaitu menyusun rancangan tindakan yang dikenal dengan perencanaan. Pada saat menyusun sebuah rancangan, peneliti menentukan titik atau fokus peristiwa yang perlu mendapatkan perhatian khusus mengenai fokus yang diamati. Pada kotak tindakan (action) di mulai dengan kegiatan-kegiatan seperti pengajuan pertanyaan-pertanyaan kepada peserta didik dalam rangka memancing berbagai tanggapan, kritik, usulan, dari apa yang telah mereka pahami serta minat mereka.

Dalam kegiatan pengamatan (observe), segala bentuk respek dari peserta didik baik verbal maupun non verbal semuanya di catat dan direkam. Kotak refleksi (Reflect) berisi perenungan, evaluasi diri dari hasil yang telah dicapai mengenai effektivitas kegiatan atau tindakan yang sudah dilakukan. Model proses dalam penelitian tindakan kelas menurut Kemmis dan Taggart terdiri dari a).Perencanaan (Planning), b).Tindakan (Action), c). Pengamatan (Observing), d). Refleksi (Reflecting). Adapun Sasaran dalam penelitian ini adalah anak usia 5-6 tahun PAUD Cempaka Pekayon. Penelitian dilaksanakan pada Bulan OktoberDesember 2015 dengan jumlah siswa 18 anak.

\section{HASIL DAN PEMBAHASAN}

Deskripsi hasil penelitian berupa data-data mentah yang diperoleh dari hasil penelitian tindakan kelas di PAUD Cempaka Pekayon Bekasi dengan jumlah siswa sebanyak 18 anak. Hasil ini diperoleh setelah menerapkan suatu pendekatan proses pembelajaran belajar kontekstual dalam rangka untuk meningkatkan hasil belajar sains permulaan. Hasil berupa data ini diperoleh setelah melakukan tindakan dari siklus I sampai pada siklus III. Pada tindakan siklus I membahas materi tentang "Klasifikasi dan Identifikasi Makhluk Hidup (binatang). Pada pelaksanaan tindakan siklus I belum menampakkan hasil belajar sains permulaan secara maksimal setelah dilaksanakan evaluasi. Pada perlakuan siklus II terjadi adanya peningkatan hasil belajar sains permulaan dengan materi atau pokok bahasan " Manfaat Hewan atau Binatang (Binatang yang menguntungkan dan binatang yang 
merugikan) di mana dalam materi ini akan menerapkan pkonsep sains sederhana dalam kahidupan sehari-hari berhubungan dengan kehidupan binatang. Dalam bahasan inipun diharapakan anak mampu menganalisis kejadian atau peristiwa sederhana dari hasil pengamatan atau observasi serta kegiatan yang sudah dillakukan. Pada siklus II ini menunjukkan adanya peningkatan hasil belajar sains permulaan dibandingkan saat pada perlakuan siklus I. Adapun pada saat siklus III penelitian tindakan membahas materi tentang "Membuat laporan sederhana hasil pengamatan tentang Hewan Liar dan Hewan Peliharaan serta Perkembangbiakan Hewan“, di mana mengharapkan anak mampu melakukan aktivitas atau kegiatan serta berpikir sintesis dan evaluasi serta kreatif' berkaitan dengan makhluk hidup (binatang). Pada siklus III diperoleh adanya peningkatan hasil belajar sains yang sangat signifikan. Namun pada penelitian ini hanya dibatasi pada III siklus saja. Kemudian penelitian ini berakhir.

Perencanaan Siklus I peneliti mengawali dengan membuat SKH atau Lesson Plan dengan membahas materi tentang "Klasifikasi dan Identifikasi Makhluk Hidup (Binatang)" . Pelaksanaan Tindakan Siklus I peneliti melakukan semua kegiatan yang telah direncanakan pada SKH atau Lesson yang sudah dibuat sebelumnya. Pada awal kegiatan tindakan siklus I mengambil topik atau bahasan tentang “ Klasifikasi dan Identifikasi Makhluk Hidup(Binatang). Kegiatan ini diawali dengan kegiatan Story Telling serta kegiatan Tanya jawab. Observasi Tindakan Siklus I peneliti bertindak sebagai observer serta pemeran utama dalam kegiatan walaupun ada guru pamong yang membantu dalam pelaksanaan kegiatan. Refleksi Tindakan Siklus I peneliti melakukan tindakan siklus I serta sudah melakukan kegiatan monitoring maka peneliti melakukan kajian ulang berupa renungan atau refleksi kegiatan. Hasil Tindakan Siklus I.

Data yang sudah diperoleh dari penelitian tindakan kelas yang dilaksanakan di PAUD Cempaka Pekayon Bekasi Bekasi Selatan dengan jumlah siswa 18 anak. Pada tindakan siklus I ini diperoleh data mentah hasil belajar sains permulaan hasil belajar kognitif 58,5\%, afektif 47,1, \%, psikomotorik $56,1 \%$. hasil belajar Siklus II kognitif $66,7 \%$, afektif $59 \%$, psikomotorik $65,7 \%$. Pada Siklus III Hasil belajar sains tersebut adalah kognitif $78,9 \%$, afektif $84,1 \%$, psikomotorik $84,3 \%$. Keterangan dari hasil yang di dapat dalam melakukan tindakan kelas dari pra siklus sampai siklus 3 adalah terjadinya peningkatan yang singnifikan dalam anak belajar sains dengan menerapkan pendekatan kontekstual ini. Perubahan yang terjadi baik kognitif, afektif maupun psikomotorik. Adapun anak-anak dalam belajar sains dengan menerapkan pendekatan ini menjadi lebih aktif, kreatif, antusias, lebih percaya diri dalam memperoleh kebenaran, meningkatkan motivasi dalam keinginan yang tinggi dalam belajar alam lingkungan sehingga hasil belajar sains lebih efektif, efisien, serta bermakna.

Hasil Belajar Sains Permulaan di PAUD Cempaka Pekayon Bekasi Selatan dengan Pendekatan Belajar Kontekstual Domain Kognitif.

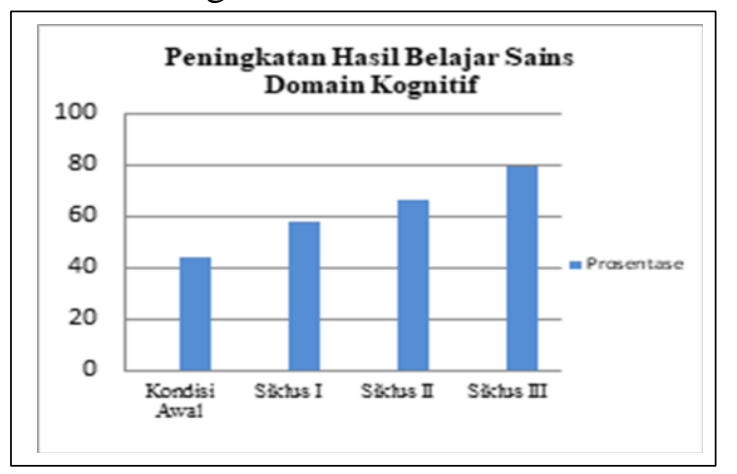

Grafik 1. Hasil Belajar Sains Domain Kognitif 
Hasil Belajar Sains Permulaan di PAUD Cempaka Pekayon Bekasi Selatan dengan Pendekatan Belajar Kontekstual Domain Afektif.

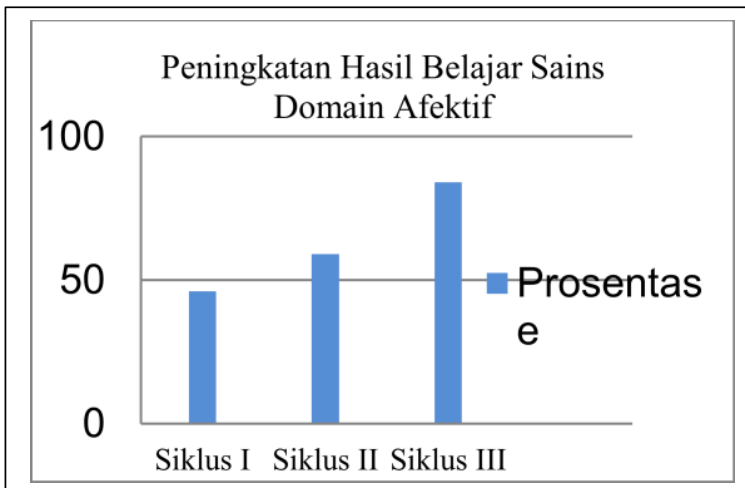

Grafik 2. Hasil Belajar Sains Domain Afektif

Hasil Belajar Sains Permulaan di PAUD Cempaka Pekayon Bekasi Selatan dengan Pendekatan Belajar Kontekstual Domain Psikomotorik.

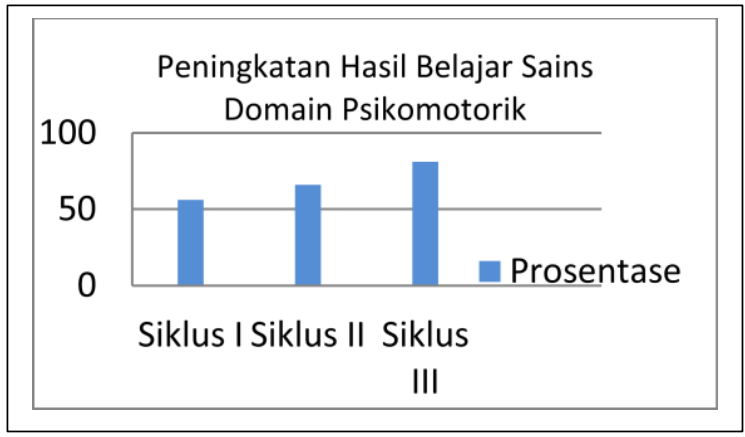

Grafik 3. Hasil Belajar Sains Domain Psikomotorik

\section{UCAPAN TERIMAKASIH}

Terimakasih kepada semua pihak yang telah memberikan dukungan baik moril maupun materiil sehinggahasil penelitian ini dapat terpublikasi dengan baik dari mulai pihak publikasi Jurnal Obsesi Universsitas Pahlawan Tuanku Tambusai Riau, Lembaga PAUD Pekayon Bekasi, dan Pihak Kampus STKIP Panca Sakti Bekasi.

\section{KESIMPULAN}

Hasil Penelitian dari Penerapan Pendekatan Kontekstual dalam pembelajaran sains Permulaan dengan menggunakan Metode Action Reseach atau Penelitian Tindakan Kelas harapannya Hasil Belajar Sains pada anak usia dini kelompok B usia 5-6 tahun meningkat, hasil pembelajaran sain menjadi lebih bermakna (meaningfull) dan anak mulai dari sejak dini tertanam sikap-sikap positif dan peka terhadap lingkungan di mana mereka hidup dan berkembang.

\section{DAFTAR PUSTAKA}

Arsyad, Azhar. "Media Pembelajaran." 20. Jakarta: Raja Grafindo Persada, 1997.

Brewer, Ann. "Early Chilhood Education Preschool Through Primary Grades." 386. University of Maddachusett Lowell Pearson, 2007.

Darmojo, Hendro, and Jenny Kaligis . "Pendidikan IPA I." 5-13. Jakarta: Departemen Pendidikan dan Kebudayaan, 1999.

Darmojo, Hendro, and Jenny Kaligis. "Pendidikan IPA II." 3. Jakarta: Departemen Pendidikan dan Kebudayaan, 1991.

Departemen Pendidikan Nasional. "Contextual Teaching and Learning (CTL) ." 3. Jakarta: Direktorat Pendidikan Dasar dan Menengah, 2003.

Dimyati, and Mudjiono. "Belajar \& Pembelajaran ." $13 . \quad$ Jakarta: Rieneka Cipta, 2006.

Hapidin, and Winda Gunarti. "Perencanaan Pengelolaan dan Evaluasi Pengajaran di Taman KanakKanak." 68. Bekasi: Ghiyats Alfian Press, 1997.

Iskandar, Srini, and Edy Hidayat. "Pendidikan Ilmu Pengetahuan 
Alam." 2. Jakarta: Departemen Pendidikan dan Kebudayaan, 1997.

Mulyadi, Seto. "Homeschooling Kak Seto." 133. Bandung: Mizan Pustaka, 2007.

Mulyasa, Endang. "Kurikulum Berbasis Kompetensi." $186 . \quad$ Bandung: Rosdakarya, 2003.

Nasution, Noehi. "Evaluasi Pengajaran." 7. Jakarta: Direktorat Jenderal Pembinaan Kelembagaan Agama Islam , 1996.

Nurhadi. "Kurikulum 2004 Pertanyaan \& Jawaban." 107. Jakarta: Grasindo, 2004.

Rogers, Cosby, and Jamet Sawyers. "Play in The Lives of Children." 3. Washington DC: NAEYC, 1995.

Slameto. "Belajar dan Faktor-Faktor yang Mempengaruhinya." $2 . \quad$ Jakarta: Rieneka Cipta, 2003.

Suharsimi, Arikunto. "Prosedur Penelitian Suatu Pendekatan Praktek." 97. Jakarta: Rieneka Cipta, 2006.

Sujana, Nana. Penilaian Hasil Proses Belajar Mengajar. Bandung: Rosda Karya, 2005.

Sujiono, Yuliani Nurani. "Metode Perkembangan Kognitif." 34-35. Jakarta: Universitas Negeri Jakarta, 2006.

Suyanto, Slamet. "Konsep Dasar Pendidikan Anak Usia Dini." 53-56. Jakarta: Departemen Pendidikan Nasional Dorektorat Jenderal Pendidikan Tinggi, 2005.

Usman, User. "Menjadi Guru yang Profesional." 29. Bandung: Rosda Karya, 1989.

Widiaatmadja. "Metodologi Penelitian Tindakan Kelas." 11. Bandung: Rosdakarya, 2008. 